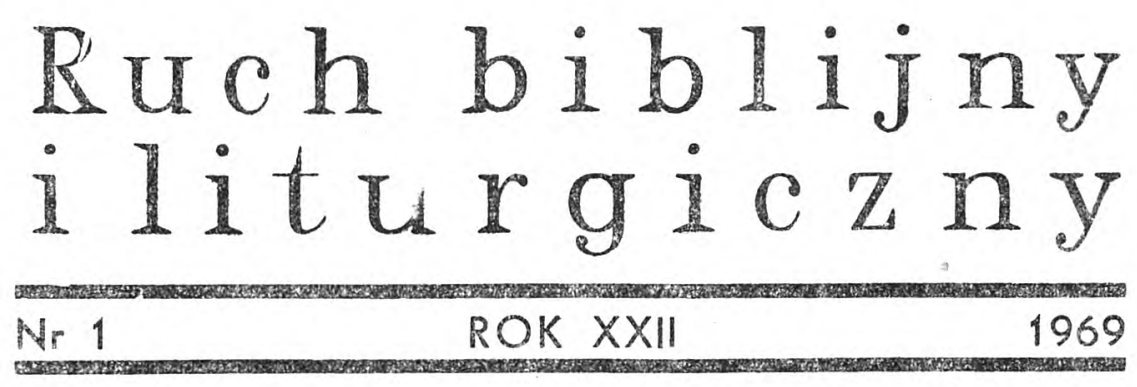

Ignacy Różycki, Kraków

\title{
KOŚCIÓL KATOLICKI NA PROGU NOWEJ EPOKI SWYCH DZIEJÓW
}

Kościót katolicki na zakręcie, l’Eglise au tornant de l'histoire oto tytuł dość licznych sprawozdań, artykułów i książek. Wszystko zaś, z czym się zapoznałem podczas synodu biskupów w Rzymie, otwarło mi oczy i upewniło mię, że Kościół katolicki - rzeczywiście $i$ prawnie - żyje już $w$ nowej epoce swych dziejów; $\dot{z} e$ okres potrydenckiej kontrreformacji został przez Drugi Sobór Watykański nieodwołalnie zamknięty $i$ należy już do przeszłości.

Nowy okres w żyoiu każdego społeczeństwa zaczyna się wszakże wtedy, gdy do osiągnięcia swego celu obiera zasadniczo mowe drogi i środki. Zadaniem Kościoła jest wprowadzenie w życie wspaniałego ideału, którego normą jest ewangeliczne prawo Boże, a żywym przykładem do naśladowania - najświętsze życie Jezusa Chrystusa. Takim pierwszym, zaskakująco nowym, a równocześnie najautentyczniej chrześcijańskim wcieleniem ducha ewangelicznego w życiu Kościoła w ostatniej dobie było potraktowanie, przez Jana XXIII, wszystkich chrześcijan nie należących do Kościoła katolickiego jako odłaczonych braci. Chociaż bowiem schizma lub herezje wyłączyły ich ze społeczności kościelnej, to jednak prawo ewangeliczne każe widzieć w nich braci i odnosić się do nich jak do braci. Tak samo wyjątkowo nowym pociągnięciem tego papieża było wyznaczenie Drugiemu Soborowi Watykańskiemu celów duszpasterskich jako właściwego przedmiotu obrad. Właśnie dlatego sobór ten zajął wyjątkowe miejsce w historii soborów powszechnych, albowiem pozostałe sobory miały na oku przede wszystkim cele dogmatyczne. Właśnie dlatego, że całą odnowę Kościoła podporządkował względom duszpasterskim, wprowadził zasadnicze zmiany w jego życiu i działalności, przez co zapoczątkował nowy okres w jego istnieniu.

Widać to dobrze już dzisiaj; wyraźnie widoczne było już podczas synodu biskupów w październiku 1967 r. Głębokie zmiany w służbie Bożej, zapoczątkowane przez soborową konstytucję liturgiczną - 
chronologicznie pierwszy z jego dekretów - są każdemu widoczne. Największą zaś nowością tej konstytucji dla katolików obrządku rzymskiego pozostanie wprowadzenie zasady, że liturgia, w której lud uczestniczy, winna być zrozumiała dla ludu; wyłączność łaciny została więc przekreślona. Troska o jednolitość metod duszpasterskich w granicach narodu i państwa podyktowała konstytucji liturgicznej wprowadzenie krajowych konferencji episkopatu, instytucji nieznanej dotychczasowemu ustawodawstwu kościelnemu. Duszpasterska troska o zbawienie chorych kazała zmienić nazwę i czas udzielania chorym piątego sakramentu, co pociąga za sobą dalekie zmiany $\mathrm{w}$ teologicznym pojęciu tego sakramentu.

Następstwem dekretów o ekumenizmie oraz o stosunku do Żydów i do wyznawców religii niechrześcijańskich jest to, że miejsce wyklinań zajął dialog $z$ braćmi odłączonymi, nacechowany miłością i poszanowaniem: widomy znak zakończenia okresu kontrreformacji. Doktrynalna teza o kolegialności biskupów z konstytucji dogmatycznej o Kościele znalazła swe praktyczne zastosowanie $w$ zupełnie nowej instytucji, jaką jest synod biskupów, wprowadzony dekretem o pasterskich zadaniach biskupów. Oświadczenie soborowe o wolności religijnej jest dowodem nowego spojrzenia na godność i prawa osoby ludzkiej, co na soborze było przedmiotem gorących dyskusji również dlatego, że jego następstwa miały sięgnąć głęboko w stosunki między jednostkami i społecznościami różnych wyznań i religii, jak również w stosunek jednostki do władzy państwowej. Bo teologowie Wielkiej Scholastyki uczyli, że wolno karać śmiercią tych, którzy szerzą herezje; prawo kanoniczne ograniczało się do zakazu zmuszania kogokolwiek do przyjmowania religii katolickiej; a sobór oświadczył nie tylko, że każdy człowiek - w granicach obiektywnego porzadku moralnego - ma prawo $w$ sprawach religijnych działać według swego sumienia, ale dodał, że jest to prawo naturalne i nieutracalne.

Zasadniczą zmianę nastawienia odnajdujemy w nowym ustawodawstwie kościelnym o poście eucharystycznym: obowiązujące do niedawna rygorystyczne przepisy miały na oku cześć Sakramentu Eucharystii, podczas gdy ich obecne złagodzenie dokonało się dla duchowego dobra wiernych; co jest zgodne $\mathrm{z}$ właściwym przeznaczeniem sakramentów, ustanowionych dla ludzi. Tę samą postawę przyjąı Paweł VI, gdy epokowym aktem w r. 1966 zreformowal anachroniczne już od lat prawo postne.

Jak szeroki i głęboki jest zasięg zmian w życiu Kościoła spowodowanych przez Drugi Sobór Watykański, wyszło na jaw podczas syncdu biskupów 1967 r., który miał zaopiniować projekty reform postulowanych przez sobór, a dotyczących rewizji prawa kanonicznego, struktury seminariów duchownych, liturgii, oraz małżenstw mieszanych. Ponadto miał on zając się niebezpieczeństwami zagrażającymi dzisiaj wierze katolickiej. Analiza pięciu zwięzłych sche- 
matów synodalnych odsłoniła mi - w olśniewającym, syntetycznym skrócie - fakt, że zmiany już dokonane i obecnie dokonujące się w Kościele są tak liczne i głębokie, iż nieodparcie narzuca się wniosek: poczynając od Drugiego Soboru Watykańskiego Kościól katolicki już żyje w nowej epoce swych dziejów, a z biegiem lat duch nowej epoki ogarniał będzie coraz to dalsze kręgi kościelnej działalności. Bardzo przekonywująco tego dowodził również sposób, w jaki biskupi na synodzie rozwiązali najtrudniejszy, doktrynalny problem.

Naprzód obiegła świat wiadomość, że synod odrzucił zarówno schemat $O$ dzisiejszych niebezpiecznych opiniach oraz o ateizmie, opracowany przez kongregację dla spraw wiary, jak i jego uzasadnienie, przedstawione przez wytrawnego tomiste i rzecznika-relatora tejże kongregacji, kardynała Michała Browne'a. Niektórzy rozdarli szaty i mówili o rewolcie biskupów na synodzie. Ale z urywkowych wiadomości, jakie udało się zdobyć z prasy i radia, nawet na odległość można było bez obawy wnosić, że ów szokujący konflikt między kongregacją dla spraw wiary a synodem biskupów miał zupełnie inne korzenie i inne znaczenie: było to starcie dwu stylów, starego i nowego; kongregacja chciała do obecnych trudności doktrynalnych zastosować stary, od wielu wieków stosowany styl rozwiązania; członkowie synodu byli przekonani, że stosowanie starego stylu kongregacji, nie prowadzi obecnie do celu, bo ani nie powstrzyma odplywu ludzi od Kościoła i od wiary, ani nie zażegna niebezpiecznych opinii filozoficznych i teologicznych. Dlatego domagali się znalezienia nowego sposobu wyjścia z trudności doktrynalnych, a jego opracowanie powierzyli komisji synodalnej, pod przewodnictwem kard. Se pera.

To, z czym spotkałem się po przybyciu do Rzymu, potwierdziło w całości słuszność powyższych wniosków. Synod przystąpił właśnie do końcowych obrad nad rozwiązaniem trudności doktrynalnych. W związku z tym nurtowaly ludzi przede wszystkim dwa pytania: Jak ustosunkuje się synod do słynnego holenderskiego Nowego katechizmu dla dorostych? Jaki sposób wynajdzie synod na teologów, odpowiedzialnych za niebezpieczne opinie?

Uważne zapoznanie się $\mathrm{z}$ schematem doktrynalnym odsłoniło mi właściwy zamysł Kongregacji dla spraw wiary. Byl on w starym stylu. Pierwsza część schematu, o niebezpiecznych opiniach, katalogowała odchylenia od nauki katolickiej, podobnie jak słynny Syllabus Piusa IX z $1864 \mathrm{r}$. oraz encyklika Humani generis Piusa XII z r. 1950. Gdyby synod biskupów przyjął schemat doktrynalny, stolica apostolska ogłosiłaby światu dokument, podobny do Humani generis, a składający się z potępien, przestróg i napomnień. Czẹść druga schematu, to zwięzły, ale świetnie zrobiony przegląd źródeł i postaci współczesnego ateizmu; tak świetny, że można by go śmiało wziąć za punkt wyjścia do szerszego, naukowego opracowania. Ale 
przyjęcie go przez synod i promulgowanie przez stolicę apostolską dałoby światu tylko jeszcze jedno potępienie ateizmu.

Ogłoszenie takiego dokumentu nie osiągnęłoby jednak zamierzoniego celu. Samym potępieniem ateizmu nie powstrzyma się bowiem odpływu ludzi od wiary, a autorom schematu chodziło właśnie o zahamowanie tego odpływu, zwłaszcza wśród młodzieży. Uroczyste potępienie wszystkich skatalogowanych odchylen teologicznych od katolickiej nauki i napiętnowanie ich autorów byłolby dzisiaj pochopne i niezgodne $z$, literą" oraz duchem orędzia Jana XXIII, wygłoszonego na otwarciu drugiego soboru watykańskiego: zahamowałoby bowiem poszukiwanie nowej interpretacji dogmatów, o którą w nim wołał; takiej mianowicie interpretacji, która by nie tylko była dostosowana do kultury naszych czasów, ale zachowała to samo znaczenie dogmatów, eundem sensum. Wszak groźba napiętnowania i jego następstw ostudziłaby skutecznie zapały teologów w tym kierunku. Czyli stary styl Świętego Officjum stał się obecnie dla Kongregacji do spraw wiary nieprzydatny.

Nad wypracowaniem nowego stylu i znalezieniem środków zaradczych na trudności doktrynalne, skatalogowane przez schemat synodalny, zastanawiała się komisja pod przewodnictwem zagrzebskiego kardynała Sepera. Uznała zaś, że odpływ młodych ludzi od Kościoła i od wiary można powstrzymać tylko wówczas, gdy się usunie jego przyczynę. Wśród tych jego źródeł, za które są odpowiedzialni ludzie Kościoła, jest również sposób podawania prawd katechizmowych przestarzały, nie liczący się dostatecznie ani z postępami współczesnej nauki, ani ze zmianami w psychice i mentalności dzisiejszego człowieka. Ten nieodpowiedni sposób sprawia, że duszpasterskie przedstawienie treści wiary bywa niekiedy odbierane jako ,drętwa mowa", zwłaszcza gdy chodzi o zagadnienia leżące na styku wiedzy $z$ wiarą, czyli szczególnie niepokojące umysł ludzki.

Synod biskupów, kierując się tymi względami, postanowił skierować do Ojca św. wniosek votum, by stolica apostolska, $w$ porozumieniu z krajowymi konferencjami episkopatów, sporzadziła pozytywne i pasterskie wyjaśnienie, (positiva et pastoralis declaratio) zagadnień składajacych się na dzisiejsza problematyke doktrynalna. $w$ tym celu, by wiara narodu Bożego miała wytyczony bezpieczny kierunek" 1. To oczekiwane wyjaśnienie winno być naprzód pozyty w ne w przeciwstawieniu do negatywnego ujęcia w schemacie, który ograniczał się do wskazania, czego należy unikać, i mówił, jak nie jest; przez to zaś nie usuwał niepewności co do tego, jak jest; ani co do tego, w co właściwie należy wierzyć: czyli nie usuwał

1 Synodus episcoporum. Relatio Comissionis Synodalis constitutae ad examen ulterium peragendum circa "Opiniones periculosas hodiernas nocnon atheismum". Vaticano 1967, s. 13. 
ani niepewności ani niebezpieczeństwa błędu. Postulowane wyjaśnienie Stolicy Apostolskiej powie natomiast, w co należy wierzyć i jak się rzeczy maja odnośnie zagadnień wysuniętych przez prob lematyke dzisiejszą. Ta zaś obejmuje nie tylko zagadnienia zupełnie nowe - jak np. ewolucjonizm a pochodzenie człowieka i duszy ludzkiej - ale także konfrontację tradycyjnych dogmatów wiary z zdobyczami nowoczesnej nauki ,czyli takie zagadnienia jak: dogmat grzechu pierworodnego a ewolucjonizm, dogmat substancjalnej obecności Chrystusa w Eucharystii wobec fizyki współczesnej. Do współczesnej problematyki należeć będą oczywiście wszystkie te zagadnienia, co do których schemat synodalny zanotował doktrynalne odchylenia teologów. Wreszcie, wyjaśnienie postulowane ma mieć charakter duszpasterski, tzn. pominie stronę czysto naukową zagadnień, a uwzględni te aspekty, które nurtują wiernych, i przestawi je w taki sposób, że wierni znajdą w nim rozwiązanie swych doktrynalnych trudności.

Znaczenie omówionego wniosku synodalnego jest wielostronne. Bezpośrednio przyczyni się do zmniejszenia trudności przeciwko wierze, a przez to do zahamowania odpływu od wiary i od Kościoła. Po wtóre, takie pozytywne i duszpasterskie opracowanie dzisiejszej problematyki religijnej będzie właściwie nowym ka techizmem dla dorosłych i współczesnym odpowiednikiem $\mathrm{Kate-}$ chizmu Rzymskiego ad parochos, ogłoszonego w r. 1566 przez Piusa V na polecenie soboru trydenckiego. Przestrzeń z górą czterech wieków, dzieląca nas od ukazania się tego znakomitego przykładu katechistyki, a przede wszystkim głębokie zmiany w spojrzeniu na świat i na człowieka, jakie się w międzyczasie dokonały, sprawiły, że Katechizm Rzymski domaga się dzisiaj albo zastąpienia go nowym katechizmem wzorcowym, albo przynajmniej uzupełnienia go omówieniem współczesnej problematyki religijnej. Dokona tego pasterskie wyjaśnienie Stolicy Apostolskiej, postulowane przez synod biskupów.

Omawiany wniosek jest również odpowiedzią synodu na osławiony, holenderski Nowy Katechizm Dla Dorosłych, De Nieuwe Katechismus ${ }^{2}$. Opracowany został przez Wyższy Instytut Katechetyczny w Nimwegen $\mathrm{z}$ polecenia episkopatu holenderskiego. $\mathrm{Na}$ czele komitetu redakcyjnego stali: prof. P. Schoo ne n berg, G. van $\mathrm{Hemert,W}$. Bless; wszyscy T. J. Przyjęty entuzjastycznie przez katolików radykalnych i umiarkowanych, wywołał głębokie zgorszenie w szeregach katolików konserwatywnych, którzy do dzisiaj stanowią jeszcze 70-80\% przyznających się do Kościoła. Do dnia dzisiejszego pozostaje przedmiotem sporu: radykalni, z Nowe j Linii, uważają, że jest za mało współczesny; konserwatywni oskarżają go o herezje. Skierowali nawet petycję do Świętego

2 Hilversum- Antwerpen- s'Hertogensboch- Roermund 1968. 
Officjum, wytykając Nowemu Katechizmowi następujące błędy doktrynalne: 1) nie przyznaje Maryi Matce Chrystusa, dziewictwa biologicznego; 2) przyjmuje poligenizm; 3) zamiast transsubstancjacji w Eucharystii przyjmuje transsignifikację i transfinalizację; 4) twierdzi, że katolicyzm uczy wszystkiego, co glosi protestantyzm; chociaż nie odwrotnie; 5) idzie za daleko w sprawie regulacji urodzin; 6) mówi tylko o zmartwychwstaniu człowieka, a nie o nieśmiertelności duszy; 7) wątpi w istnienie aniolów. Jego oryginalność i atrakcyjność katechetyczna objawia się w tym, że do Boga podchodzi od strony człowieka i religijnej wiary; to zaś podejście rozwija na osnowie egzystencjalistycznej fenomenologii M. Heideggera: Punktem wyjścia jest tajemnica bytowania ludzkiego, dla którego poszukuje interpretacji.

Wszystko to sprawiło, że Nowy Katechizm stał się rychło przedmiotem ogromnie żywego zainteresowania. Stolica apostolska wyznaczyła komisję, złożoną z siedmiu kardynałów, dla zbadania zarzutów doktrynalnych, wysuniętych przeciwko niemu. Obok kardynalów konserwatywnych, jak Ottaviani, Browne, Journet, zasiadają w niej postępowi, jak Alfrink, Döpfner. Zadanie komisji jest jednak bardzo trudne, gdyż błędy Nowego Katechizmu nie polegaja na sformułowaniach pozytywnie błędnych, ale albo na przemilczeniach, albo na sformułowaniach zbyt ogólnikowych, wstawionych przy tym $w$ fałszywą perspektywę egzystencjalistyczną. O dziewictwie Maryi Panny pisze np. w sposób nieokreślony, że dopuszczone być może pożycie małżeńskie. Podobnych błędów naliczyć by można znacznic więcej niż siedem, a ich usunięcie wymagałoby wyprostowania perspektywy filozoficznej oraz wprowadzenia ścisłych sformułowań: czyli zasadniczej przeróbki. Nic dziwnego, że komisja kardynałów jeszcze się nie wypowiedziała w sprawie Nowego Katechizmu.

Kontrowersyjność Nowego Katechizmu była powodem, że w publicznej sprzedaży ukazało się tylko tłumaczenie angielskie, wydane przez nowojorski oddział Herdera ${ }^{3}$. Jest to jednak wydanie pozbawione kościelnego imprimatur, gdyż biskup Joy ce z Burlington $\mathrm{w}$ ostatniej chwili wycofał je na skutek protestu kardynała A Ifrinka, umotywowanego tym, że Nowy Katechizm był układany z myślą o specyficznych warunkach, w jakich dzisiaj żyją katolicy holenderscy. Europejski Herder z Freiburga okazal znacznie więcej roztropności niż jego amerykański oddział, albowiem tłumaczenie niemieckie wydał tylko w ograniczonej liczbie egzemplarzy studyjnych dla biskupów i profesorów, przesyłanych bezpośrednio do rąk zainteresowanych osób, z wyłączeniem handlu księgarskiego.

Synod biskupów nie był uprawniony do zajmowania się wprost

3 New York (Herder and Herder) 1967. 
zagadnieniem doktrynalnej poprawności Nowego Katechizmu, ale omawiany wniosek synodalny jest praktycznie bardzo doniosłym zajęciem stanowiska wobec holenderskiego katechizmu: ponieważ to autentyczne współczesne przedstawienie duszpasterskie katolickiej nauki okazało się bardzo sporne, niechaj Stolica Apostolska wypracuje nowe, równie wspólczesne a wolne od zarzutów nieprawowierności.

Wreszcie oddziaływanie tego samego wniosku synodalnego obejmuje swym zasięgiem również teologów, których przedwczesne opinie tyle troski przysparzają Kongregacji do spraw wiary i biskupom. Katechetyczne rozwiąanie i przedstawienie jakiegoś problemu nie może być hermetycznie odizolowane od naukowego, ale istnieje między nimi ścisły logiczny związek: rozwiązania katechetyczne rzutują na naukowe i na odwrót. Przygotowane przez Stolicę Apostolską pozytywne, chociaż duszpasterskie rozwiązanie dzisiejszej problematyki stanowić będzie dla teologów kryterium, przez odniesienie do którego będą sprawdzać doktrynalną poprawność swych rozwiązań. Tą drogą zmniejszy się automatycznie ilość odchyleń w teologii; ta zaś mogła będzie swój wysiłek skierować ku stworzeniu naukowo teologicznej syntezy starego z nowym, czyli wejść na drogę, która prowadzi ku Wielkiej Teologii.

Ale wypracowanie pozytywnego, pasterskiego rozwiązania dzisiejszej problematyki religijnej nie będzie mogło się dokonać bez współpracy teologów i bez żywych dyskusji między nimi. W ogóle troska teologów zajęla poczesne miejsce w przyjętej przez synod relacji - relatio komisji doktrynalnej. Synod - jak powiedziano nie aprobował potępienia wszystkich odchyleń od prawowiemości, a za podstawę do olkreślenia nowego stylu w odniesieniu do teologów obrał bezsporny fakt, który tak opisal: Nie naleizy się dziwić..., że owocna i najbardziej na czasie będaca odnowa, jaka dla Kościoła przyniósz II Sobór Watykański - która zmienita wiele zwyczajów $i$ sposobów myślenia, uważanych $z a$ niezmienne, $i$ dała podniete wielka do nowej refleksji oraz do rozpoczecia nowego stylu życia chrzéścijańskiego i liturgii - jest źródtem trudności a nawet niepewności ${ }^{4}$. Gdzie trudność i niepewność, tam poszukiwanie właściwego rozwiązania połączone jest $z$ niebezpieczeństwem blądzenia, zwłaszcza wtedy, gdy źródła objawienia nie zawieraja gotowej odpowiedzi na pytania nowo powstałe. Najlepszym sposobem na najszybsze znalezienie prawdziwej odpowiedzi na nową problematykę jest nieskrępowana dyskusja i wspólpraca wielu teologów z różnych ośrodków. Gdy chodzi o nową problematykę nie należy rozpaczać nad każdym błędnym rozwiązaniem ani też od razu go potępiać.

4 Synodus episcoporum. Relatio Commissionis Synodalis constitutae ad examen ulterium peragendum circa "Opiniones periculosas hodiernas necnon atheismum". Vaticano 1967, s. 7. 
To rozumowanie leżało $u$ podstaw nowego w historii Kościoła postulatu synodalnego wolności badań teologicznych: Aby zaś to swoje zadanie mogli należycie wypetnić, należy im dać bez watpienia taka wolność $w$ poszukiwaniu nowych rozwiazań $i$ udoskonalaniu dawnych, jakiej sie domaga sprawiedliwość, iusta libertas nova inquirendi veteraque perficiendi ${ }^{5}$. Już sama natura katolickiej teologii wskazuje, że wolność badań nie może być w niej nieograniczona: ponieważ z założenia jest naukowym opracowaniem treści katolickiej wiary, przestałaby być katolicką teologią, gdyby popadła w sprzeczność z wiarą Kościoła. Dlatego granice postulowanej wolności badań synod biskupów określił następującymi słowami: Stuszna wolność winna zamykać się zawsze $w$ granicach słowa

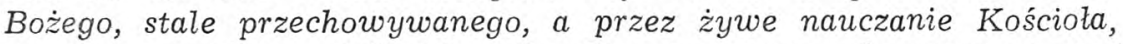
przede wszystkim zaś Namiestnika Chrystusowego, głoszonego $i$ wyjaśnianego ${ }^{6}$. Tak określona wolność badań jest równoznaczna $z$ otwarciem dla teologów katolickich drogi, która doprowadzi ich do Wielkiej Teologii. Ustosunkowanie się Stolicy apostolskiej do teologów holenderskich wskazywałoby na to, że postulat wolności badań teologicznych jest $\mathrm{w}$ Kościele istotnie realizowany.

Dopełnieniem żądania wolności badań, skierowanego pod adresem Kościoła, były dwa napomnienia zwrócone do teologów: wolność badań powinna być mianowicie połączona z uczciwością naukową $\mathrm{w}$ badaniach oraz poczuciem odpowiedzialności za słowo, pisane i mówione, w rozpowszechnianiu wyników badań. Z natury teologii katolickiej wynika zaś, że uczciwość naukowa objawia się w niej tak, że teologowie służą słowu Bożemu, a nie posługują się nim jako narzędziem dla poparcia własnych przekonań. A poczucie odpowiedzialności wykażą teologowie, jeśli wyniki swych badań będą ogłaszać $\mathrm{w}$ taki sposób, że przyczynią się do rozbudzenia miłości i poszanowania dla słowa Bożego i dla Kościoła nauczającego. W tym celu należy obrać za punkt wyjścia to, co pewne; dopiero na drugim miejscu ciągłość tej samej wiary; jeśli zaś przedstawia się hipotezy, to na końcu oraz w takim kontekście i w taki sposób, by nie mogły być zrozumiane przez odbiorców inaczej niż zamierzał autor.

Przejawem nowego stylu w rozwiązywaniu trudności doktrynalnych jest także inny wniosek synodu do papieża. Mianowicie ośrodki teologiczne poza Rzymem utyskiwały, że papież i Święte Officjum ograniczają się do doradców $z$ ciasnego kręgu teologów rzymskich i ich opinie podnoszą do rzẹdu nauki katolickiej, mimo, że nie są jeszcze - zdaniem tychże ośrodków - teologicznie dojrzałe. Na tym tle wyrastała wyraźna niechęć do Rzymu, który

5 tamże s. 11.

6 tamże s. 11. 
nie ,dostrzegał" rzekomo teologów pozarzymskich. Z drugiej strony zaś biskupów i Kongregacjẹ do spraw wiary niepokoił brak poczucia odpowiedzialności za słowo u teologów katolickich spoza Alp, którzy niejednokrotnie siali niepokój w umysłach wiernych. Synod biskupów nie ograniczył się do przypomnienia wszystkim teologom o odpowiedzialności za słowo - o czym wyżej była mowa - ale w tym samym celu skierował do Ojca św. wniosek w wielkim stylu nowy: by została ustanowiona komisja teologiczna złożona z teologów różnych szkót, mianowanych na czas ograniczony, odznaczających sie madrościa i cieszacych się sława naukowości, a pochodzacych $z$ różnych części Kościoła tak Zachodniego jak Wschodniego - której zadaniem byłoby - z zachowaniem wolności nauki zgodnej $z$ prawem, legitima libertate scientifica servata służyé, pomoca Stolicy Świẹtej a w szczególności Kongregacji do spraw wiary, zwłaszcza w odniesieniu do zadan doktrynalnych większego znaczenia?.

Członków Komisji teologicznej mianuje papież spośród tych, którzy przedstawią konferencje krajowych episkopatów. Te z kolei kierują wprzód zapytanie do Wydzialów Teologicznych, którzy teologowie posiadaja wymagane przymioty do czlonkostwa. Zasiadający w Komisji winni zaś lączyć głęboką wiedzę naukową z mądrością i roztropnością życiową; sama wiedza nie wystaczy. Wniosek synodu postuluje, by Komisja była prawdziwie przedstawicielka całej teologii calego Kościoła, i dlatego domaga się, by zasiadali w niej nie tylko przedstawiciele różnych szkół teologicznych, ale także geograficznie różnych części Kościoła, tak z Za.chodu jak z Wschodu. Jej zadaniem będzie pomóc Stolicy Swiętej w rozwiązywaniu trudniejszych zagadnień doktrynalnych.

Synod, wierny sobie, jeszcze raz podkreśla, że w pracach tej Komisji winna być zachowana uprawniona wolność naukowa. Jeśli uwzględnimy, że zasiadać $\mathrm{w}$ niej będą przedstawiciele różnych szkół zamysł synodu stanie się od razu jasny: w obrębie Komisịi winny się ścierać ze sobą poglądy różnych szkól teologicznych; taka rzetelnie naukowa i wolna dyskusja przygotowuje wszechstronnie zajęcie doktrynalnego stanowiska przez Stolice Swieta, zwłaszcza w zagadnieniach naukowych a ważnych, na które źródła objawienia nie daja gotowej odpowiedzi. Poparcie udzielone przez synod dyskusjom między różnymi szkołami teologicznymi jest oznaką ducha nowej epoki: Kościół dialogu z niekatolikami nie może nie popierać dialogu między teologami różnych szkól.

Wniosek o utworzenie Komisji teologicznej jest nie tylko oznaka nowego stylu, ale także mistrzowskim pociągnięciem taktycznym. Utworzenie prawdziwie reprezentatywnej Komisji międzynarodowej odbierze ośrodkom pozarzymskim powód do utyskiwań na nie-

7 tami்e s. $11-12$. 
docenianie przez Stolicę Apostolską, a udział w pracach Komisji sprawi, że teologowie całego świata staną się rzeczywiście wspólodpowiedzialni za kształtowanie się doktryny katolickiej; to zaś pogłębi w nich poczucie odpowiedzialności, o które woła synod i Kościół.

Omówione wyżej inicjatywy synodu w sprawach doktrynalnych pozwalają na całkowicie pozytywną ocenę instytucji synodu: gdyby pierwszy w dziejach Kościoła synod biskupów nic innego nie zdziałal poza bardzo roztropnym i nowym ustawieniem zagadnień doktrynalnych, już przez to samo dowiódł, że jest instytucją pożyteczną, którą należało powołać do życia.

Jeśli inicjatywa twórcza synodu nie była tak wielka w sprawie reformy liturgii, kodeksu prawa kanonicznego, i struktury seminariów duchownych oraz Wydziałów Teologicznych, było to zasługą komisyj, powołanych do ich przeprowadzenia: nowy styl idacy naprzeciw wymaganiom czasu, był $\mathrm{w}$ ich projektach tak widoczny, że synod biskupów nie znalazł nic istotnego do dorzucenia.

Zjawiłem się w Rzymie, gdy synod już zaaprobował przedstawione mu projekty reformy prawa kanonicznego oraz struktury nauczania $w$ seminariach duchownych i Wydziałach Teologicznych, a na ustach wszystkich była $\mathrm{M}$ is a normativa, czyli msza wzorcowa, odprawiona w kaplicy sykstyńskiej dnia 24. X. 1967 r. dla członków synodu biskupów. Jej układ, or do Miss a e, był w części poprzedzającej kanon - zupełnie nowy i odbiegal nie tylko od obrządku rzymskiego: miał aż 3 czytania, z Starego Testamentu, z Listów, z Ewangelii, a wszystkie modlitwy tzw. małego kanonu, na ofiarowanie, zostały skreślone; również kanon Mszy wzorcowej dopiero od per ipsum et cum ipso podejmowal modlitwy kanonu rzymskiego, a poprzedzająca część modlitwy eucharystycznej, bardzo pięlkna, zaczerpnięta byla z Tradycji a oos tolskiej św. Hipolita ( $\dagger$ 235/236). Układ Mszy wzorcowej mial przejść do przyszłego mszału rzymskiego, przygotowanego przez Radę dla wykonania konstytucji o świętej liturgii. (Consilium ad exequendam constitutionem de Sacra Liturgia). Wedlug tego nowego układu już odprawiały się Msze św., na próbę, w diecezji Lugano w szwajcarskim Tessynie; i to calkowicie w języku włoskim.

Ta_sama Rada dostarczyła również członkom synodu całkowity układ przyszłego brewiarza na jeden tydzień, mianowicie na dni od 12 do 19 listopada 1967, aby nad przyjęciem reform przygotowanych przez Radę głosowali z pełna znajomością sprawy.

Jednak podczas synodu podawano sobie $\mathrm{z}$ ust do ust wiadomość, jakoby Misza wzorcowa nie znalazła uznania w oczach synodu i jakoby nie podobały się szczególnie melodie do śpiewów, archaizujace, oparte na pentatonice, prymitywne. W rzeczywistości biskupi z synodu zgłosili zastrzeżenia jedynie co do szczegółów; uważali, 
że wprowadzenie aż trzech czytań nadmiernie przedłuży Mszę św. tak, że braknie czasu na homilię. W zasadzie zaaprobowali zaś zarówno układ Mszy wzorcowej jak i brewiarza, tak że już dzisiaj wiadomo, jak dalece przyszła Msza i przysziły brewiarz obrządku rzymskiego różnić się będą od dzisiejszej swej postaci.

Jeśli poddamy ocenie posoborowe ustawodawstwo liturgiczne oraz

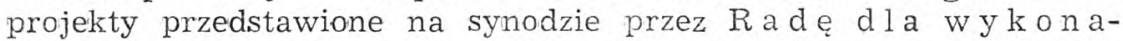
nia kostytucji o świętej liturgii, dojdziemy do dwóch oczywistych wniosków. Dopiero posoborowe ustawodawstwo realizuje coraz to w szerszym zakresie zasadę, że liturgia przeznaczona dla ludu winna być przez lud rozumiana. Jesteśmy świadkami, jak języki narodowe coraz bardziej wypierają łacinę, a zjawisko to wydaje się nieodwracalne wobec tego, że znajomość łaciny w cał̌ly świecie staje się coraz mniejsza. Ale omówiony wyżej projekt Mszy wzorcowej i przyszłego brewiarza zdradza jednak ponadto now y sty l, który dowodzi, że duch nowej epoki kieruje pracami $\mathrm{R}$ a dy d la wy konania konstytucji o świętejliturgii.

Układ Mszy św. obrządku rzymskiego, będący dzisiaj w użyciu, jest właściwie dziełem historycznego przypadku. Jemu przypisać należy, że do niedawna oprócz ewangelii dnia mieliśmy jeszcze drugą tzw. ostatnią ewangelię; jemu zawdzięczamy modlitwy na ofiarowanie, dublujące modlitwy kanonu, które do liturgii rzymskiej dostały się z liturgii gallikańskiej. Reforma liturgiczna, podjęta przez sobór trydencki, ograniczała się do usunięcia niezdrowych przerostów. Pierwsze kroki posoborowej reformy, takie jak skreślenie ostatniej ewangelii, psalmu Judica me i modlitwy Placeat tibi, mogły nasuwać obawę, że pójdzie ona $\mathrm{w}$ ślady trydenckie $\mathrm{i}$ będzie jej drugim wydaniem. Tymczasem przedstawiony synodowi biskupów układ Mszy wzorcowej i brewiarza jest tworem zasadniczo nowym, a nie ulepszonym wydaniem dotychczasowych ukladów. Otrzymamy niebawem właściwie nowy brewiarz, a nie przeróbke dzisiejszego. Będąca w toku reforma liturgiczna nie jest więc drugim wydaniem trydenckiej.

Po wtóre, układy Mszy i brewiarza, przedstawione synodowi, odznaczają się tym, że $z$ naukowa metodycznościa realizuja cel, do którego zostały przeznaczone: układ Mszy wzorcowej został w całości tak pomyślany, by wyraziściej unaocznić wiernym znaczenie sprawowanej tajemnicy wiary oraz wciągnąc wiernych do czynnego udziału w liturgii mszalnej; przyszły brewiarz jest konsekwentnie tak układany, by był modlitewnikiem kapłanów duszpasterzy oraz księga czytań duchownych. Związek z officjum chórowym zakonników zostanie zerwany; zniknie nawet nazwa jutrzni, matutinum, a jej miejsce zajmie nazwa officjum lectionis, godzina czytań. Duszpasterz nie może poświęcić na modlitwe tyle samo czasu co zakonnik, wolny od duszpasterskich zajęć: dlatego psałterz odmawiany będzie w cyklu miesięcznym, a nie tygodniowym; dlatego godzina brewiarza będzie się składać najwyżej 
z trzech psalmów, a liczba godzin zostanie zredukowana do pięciu. Będziemy więc mieć: godzinę czytań, laudesy, godzinę pośrednią, nieszpory i kompletę; a laudesy, nieszpory i kompleta będą tak ułożone, że będą miały charakter modlitw porannych względnie wieczornych. Czytania będą tylko dwa: z Pisma św. i Ojców, względnie - w uroczystości świętych - z Pisma św. i hagiograficzne. W okazowym doborze czytań na jeden tydzień listopada, jaki otrzymali do wglądu członkowie synodu, widać pedantyczną staranność o to, by każde czytanie zawierało bogatą treść, zachęcająca do rozmyślania. Zrezygnowano $\mathrm{z}$ dotychczasowej lektury urywków wszystkich ksiąg Pisma św. według kolejności, jaką zajmują w kanonie. Ta zaś metodyczność jest charakterystyczną cechą epoki, w której żyjemy. Czy wiek XX nie jest powszechnie uważany za wiek panowania nauk? A nie ma nauki bez metody.

Kiedy przybyłem do Rzymu, synod biskupów już uporał się z zagadnieniami reformy studiów kościelnych oraz prawa kanonicznego. O tych sprawach nie będę się szerzej rozwodził dlatego, że w tej pierwszej części studium chcę przedstawić własne refleksje zrodzone $\mathrm{z}$ własnych doświadczeń. Muszę jednak wspomnieć o tym, że bezpośrednio po soborze liczono, iż prace nad reformą prawa kanonicznego potrwają trzy lata, a w październiku 1967 r. było już pewne, że zabiora co najmniej siedem lat. Albowiem pierwotnie myślano jedynie o dostosowaniu istniejących przepisów kanonicznych do ustawodawstwa soborowego, a w ciągu prac nad reformą okazało się, że należy od podstaw przebudować prawo kanoniczne, jeśli jego reforma na dłuższy okres czasu ma być pożyteczna Kościołowi. Okazało się także, iż podstawy prawa kanonicznego należy poszerzyć o dwie nowe zasady, które dobrze zdały egzamin w nowoczesnym ustawodawstwie świeckim. Jest to principium subsidiarietatis, pociągające za sobą większa autonomię biskupów, oraz instytucji trybunałów administracyjnych dla obrony jednostki przed samowolą rządcy. Oparcie prawa na nowych zasadach, to również znak nowego stylu i nowej epoki.

Kraków

KS. IGNACY RÓŻYCKI

\section{Ks. Wlodzimierz Wielgat, tomża}

\section{WIARA W STARYM TESTAMENCIE W ŚWIETLE FILOLOGII | TEOLOGII}

Czyn jest wiara? Jaka treść wyraża słowo „wierzyć”? czy wierzyć znaczy tyle, co przyjąć rozumem za prawdę wszystko, co Bóg objawił, jak głosił Sobór Trydencki a potem Watykański I ${ }^{1}$, kładąc

1 Por. określenia wiary podane przez Sobory: Trydencki i Watykański I, Dz 798, 1789. 